\title{
Toward a Business Resilience Model: The Case of Sharia Property in Surabaya Raya Area during COVID-19 Pandemic
}

\author{
Aulia Adzkia Fauzi and Raden Aswin Rahadi
}

\section{ABSTRACT}

This study aims at examining how sharia property can build resilience during COVID-19 pandemic and to provide a business resilience model by exploring its capabilities to be resilient during COVID-19 pandemic. The empirical results from a case study of sharia developer located in Surabaya Area, show that the strengthening of the developers' commitment, strengthening cash flow management, enhancing, and deploying knowledge stock about sharia property, and emerging dynamic capability to respond to the shock and maintain the business continuity of sharia property during COVID-19 pandemic.

We contribute to extant business and management literature about the concept of business resilience of sharia property by proposing a model about how sharia property builds its business resilience during COVID-19 pandemic.

Keywords: COVID-19, resilience, sharia property.

\section{INTRODUCTION}

The COVID-19 pandemic that has started in Wuhan, China, has been spread all over the world since the end of 2019 [1]. As of 13 July, Indonesia has reported approximately 2.67 million cases, the highest in Southeast Asia [2]. In terms of additional daily cases, Indonesia ranks first both in Asia and the world. The increased number of cases of COVID-19 has affected the world economy including Indonesia. The COVID-19 pandemic that has been established by the UN, is
Submitted : June ${ }^{* *}, 2021$

Published : August 13, 2021

ISSN: 2507-1076

DOI: $10.24018 /$ ejbmr.2021.6.4.986

\section{Aulia Adzkia Fauzi*}

Master of Business Administration, School of Business and Management, Bandung Institute of Technology, Indonesia.

(e-mail: aulia_adzkia@sbm-itb.ac.id) Raden Aswin Rahadi

Asisstant Professor, School of Business Administration, Bandung Institute of Technology, Indonesia.

(e-mail: aswin.rahadi@sbm-itb.ac.id)

*Corresponding Author not only a concept related to health sector, it also brings up changes that may affect all sectors and professions [3]. The COVID-19 outbreak seen as an unpredictable phenomenon, has a different characteristic than past crises which has been experienced in world time history [4], pandemic has disrupted the economic sectors and the economic system and especially in developing economies had faced a crisis environment and had to face serious risk of a greater loss in their economies [5].

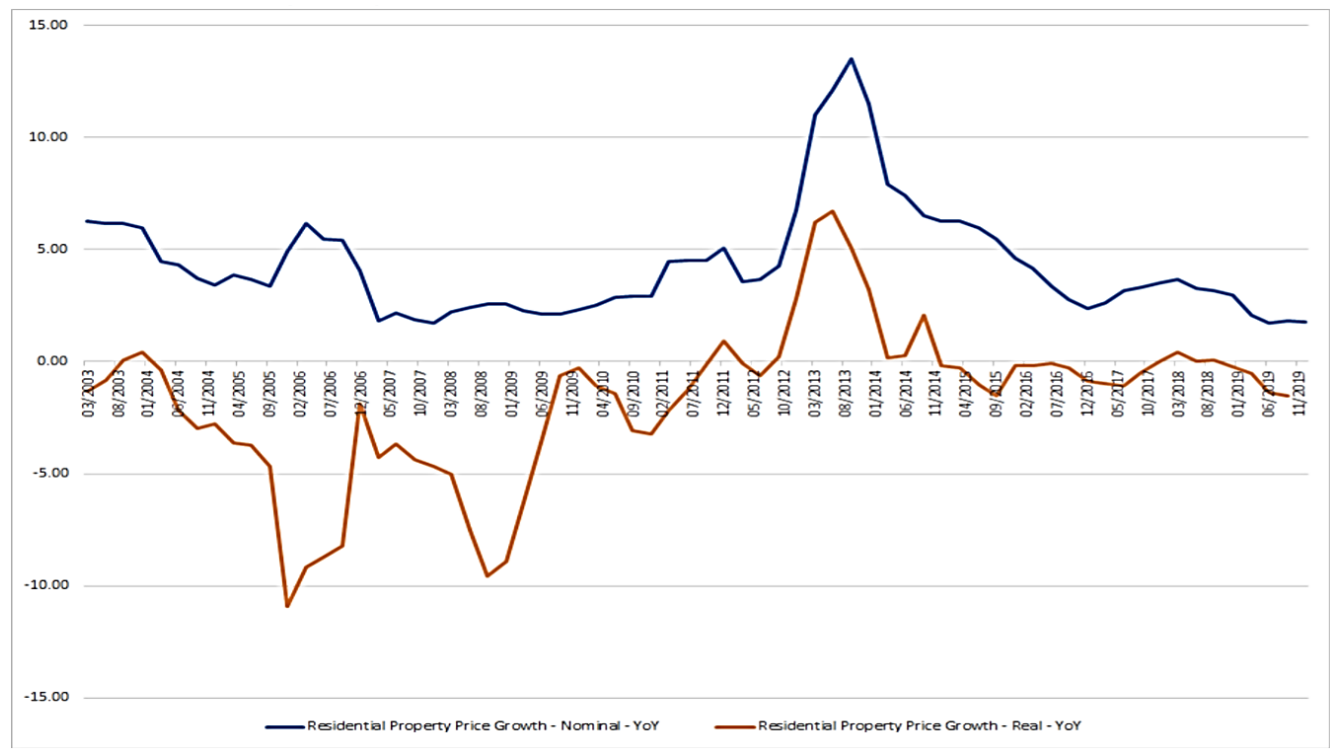

Fig. 1. Property Trend Price [7]. 
Property sector is one of the sectors that affected by COVID-19. As can be seen from the dynamic trend of prices (Fig. 1), Indonesia's housing property market has now reached the maturity/ stabilization stage. Current average price increase has decreased from 14\% in 2013 to 3\% in 2017 and 2018, even in the quarter in both 2019 the average price increase was lower, around $2.5 \%$ [6]. Indonesia's housing property market growth has been slowing down growth since 2014 and is likely to head into the recovery period from the year 2020. But, as COVID-19 pandemic hit, the growth of the market is decrease as shown on Fig. 2. The condition is even worse when many creditors' jobs have impacted by COVID19. It increases the NPL (Fig. 3) and make most of banks tightened up their selection for the new credit application. Then, it affects the real estate financing that most of the customers are obstructed by a strict regulation.

\section{Residential Property Sales Growth (YoY)}

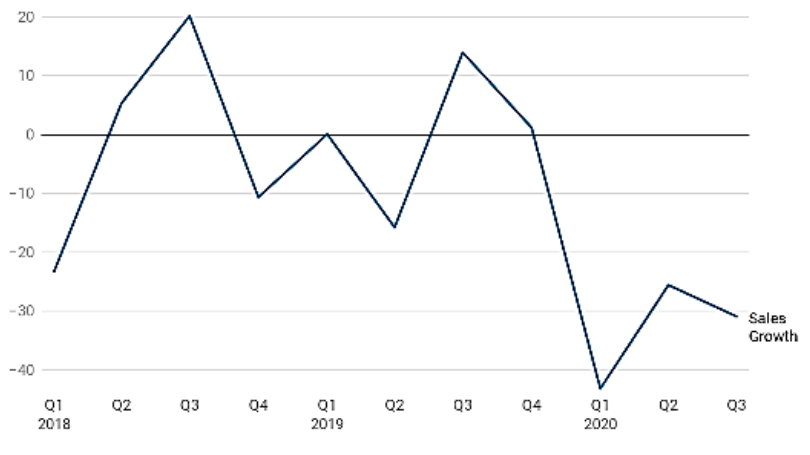

Fig. 2. Housing Property Growth (YoY) [8]

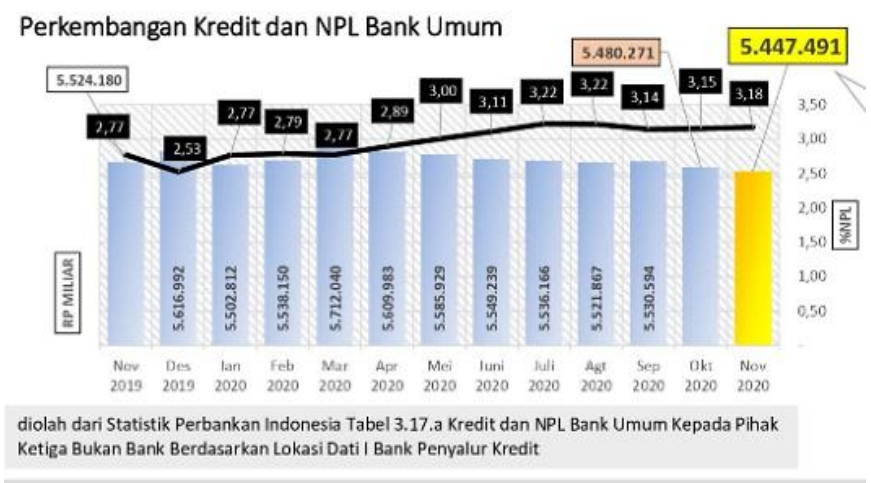

Fig. 3. Non-Performing Loan [9].

Indonesia has a large of a Muslim population, that attract many developers to offer and apply property loan financing based on the concept of sharia in its marketing strategy. Sharia values are invested in goods and services is part of the company's marketing strategy. Some developers offered some easiness features for their potential customers such as not involving banks, no usury (riba), no changes in initial contract, without confiscation, without penalty, without insurance, and without BI checking. Developers hope that the Islamic label will provide more value help increase the attractiveness of the goods and services offered. Meanwhile in the consumer perspective, it is an attractive form of offering because at first glance it seems more profitable than using conventional KPR through conventional banking. Especially for consumers who are aware with sharia principle.
Meanwhile, although in the middle of crisis, sharia property seems to be resilient to adapt with the condition. Based on the Rumah.com Property Outlook 2020 research, sharia property purchases and financing are gaining popularity, especially among low-income people (Masyarakat Berpenghasilan Rendah - MBR) [10]. Deputy Secretary General of the DPP Association of Indonesian Real Estate Companies (REI) for Sharia Property, Royzani Sjachril, said that currently, sharia housing is not experiencing too much turmoil due to covid-19 pandemic shock. According to him, the risk of bad loans or nonperforming loans (NPL) experienced by customers can still be reduced [11]. This is because sharia property applied easier financing application.

\section{A. Research Objectives}

This study aims at examining how sharia property can build resilience during COVID-19 pandemic and to provide a business resilience model by exploring its capabilities to be resilient during COVID-19 pandemic.

\section{B. Research Scope and Limitation}

This research is going to conduct on certain developer and or agency property that hold a (pure) sharia principle. This research is limited in Surabaya Raya area, which is originally only conclude of three cities, Surabaya, Sidoarjo, and Gresik, but I added up cities surroundings the Surabaya area which has potential projects, so the object concludes of five cities, Surabaya, Sidoarjo, Mojokerto, Gresik, and Tuban. The sharia property is limited to four projects which are from two developer and or agency, because it is limited to company that hold (pure) sharia principle. This study is also limited to do a research in housing property.

\section{LITERATURE REVIEW}

\section{A. COVID-19 Pandemic Effect to Real Estate Industry}

The effect of the pandemic on the real estate market was discussed in terms of number or volume of transactions, use of credit and real estate values. A survey conducted by Bank Indonesia (BI) noted that sales of new homes fell drastically during the COVID-19 pandemic. All types of housing recorded a decline. In the first quarter of 2020, home sales fell by $-43.2 \%$ (YoY) and improved slightly to $-25.6 \%$ in the following quarter as shown on Fig. 2. According to BI, the decline in housing sales is coming from the impact of the COVID-19 pandemic, so potential customers tend to hold their desire to do property survey. Another impact of COVID19 pandemic is from economic side, which the growth of economic is considering to be slow but contrary, the interest rate and down payments are still considered high. In addition, the slower economic growth is impacted some people with certain jobs and those who are in a house mortgage, are still facing a difficult situation that give implications to high NPL (Fig. 3). Then it makes the bank become more selected to the candidates who applied for the KPR. Most people who have informal jobs are struggling to get acceptance for the credit. Then, they are trying to find other options of getting their properties in the middle of pandemic situation.

Housing property growth during COVID-19 pandemic is very dynamic in a short time. Affected by the corona 
pandemic, sales volume and property prices have decreased in year-on-year. However, since the easing of social restrictions was enforced ("new normal establishment"), consumers have started to look for housing again. According to Bank Indonesia data, the growth for the housing property is showing a positive trend in quarter-to-quarter (Fig. 4).

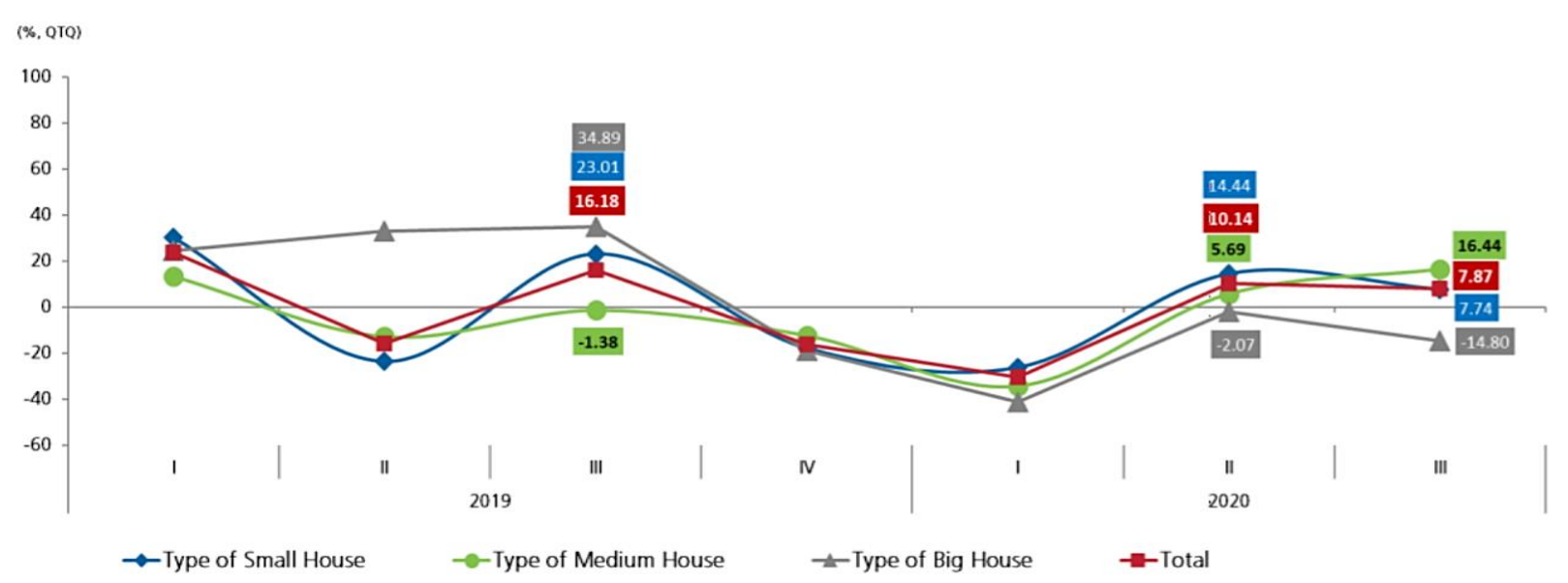

Fig. 4. Housing Property Sales Growth (QoQ) [8].

\section{B. Sharia Property}

Sharia property consists of two different terms, namely "property" and also "sharia". Property is a property that is owned by someone or groups to which has an exclusive right. As for the form of property usually refers to land as well as buildings. Meanwhile, sharia is a law in Islam which guide for all of its people. So, property Sharia is property of ownership be it land or building ownership is obtained in a manner according to sharia / Islamic law [12]. In general, Islamic property is a type of system property the transactions are carried out in accordance with Islamic sharia, namely as follows [13]:

- Transactions without usury (riba)

- Sale and purchase contract ( akad)

- The price has not changed since the contract

- No insurance

- Without confiscation

\section{Business Resilience}

Resilience is the ability of a system to maintain certain functions, processes, or reactions after experiencing a disturbance [14]. Resilience is defined as the capacity of a system and ability to tolerate disturbance and maintain its structure and function [15], [16]. Resilience is often, viewed as a good thing. If an ecosystem is resilient, or if human society is resilient, then they will be quite capable of withstanding the disturbances that they face [14].

Business resilience is defined as business continuity, emergency management, and disaster recovery to build the ability to quickly adapt and respond to risk opportunities and maintain business operations continuously to be a more trusted business by partners and enables sustainable growth. Business resilience can be determined as a business that can respond to these ever-changing market conditions quickly will be able to not only weather the current storm, but also find unexpected opportunities to gain an edge [17].

\section{Conceptual Framework}

The conceptual framework is used to be a guideline for author to conduct research and get a deeper analysis about a problem over the research. As Fig. 5, the problem that is arisen is the sharia property resilience, and in this research, author is going to analyse how the related parties build their resilience. Through this research, author is going to provide a more detailed framework of sharia property resilience. Before analyse it, this initial conceptual framework helps author to get a picture about the research. From its initial conceptual framework, sharia property resilience is initially built from its initial values and knowledge about the business and principles also values. Then, it all combines with the developers' capabilities in responding kind of shocks through their experiences in running the business to build a resilience at the end of the adjustment through the new condition.

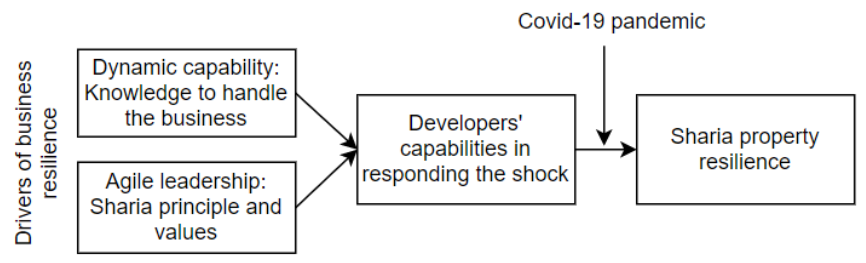

Fig. 5. Conceptual Framework.

\section{METHODS}

This research is conducted by using qualitative methods. Qualitative methods use descriptions and categories (words) to study human experiences and realities from the subject's perspective [18]. Qualitative research thus contrasts with quantitative research, which focuses on the way the world is understood in researchers' minds, usually using abstract scientific concepts and terminology [19]. This research is more focused on the grounded theory.

This study focuses on sharia property in facing a "huge" shock during COVID-19 pandemic that affect the property sector in general. This study uses case study approach to examine the sharia property's business resilience because there is a research limitation in conducting this research. Author interviewed some key resources in the company and observed its business to conduct the result. This research uses point of views of key resources whom facing the shock to be resilient. In obtaining interview, author used a purposive sampling to determine whom to be interviewed. Purposive sampling, one of the most common sampling strategies, 
groups participants according to preselected criteria relevant to a particular research question [20]. According to [20] sample size for purposive sampling is depend on the resources and time available, as well as the study's objectives. The number of respondents can continue until no new themes emerge from the interviewee because the data will reach saturation. Data saturation is shown when no further information arises from the respondents who selected based on the industry. So, this study conducted by interviewing six person who are experts in that field. The interviewee is chosen based on their role and experience in making decision through "hard" situation. So, this study is actually going to measure and discover about how sharia property can build its resilience during COVID-19 pandemic.

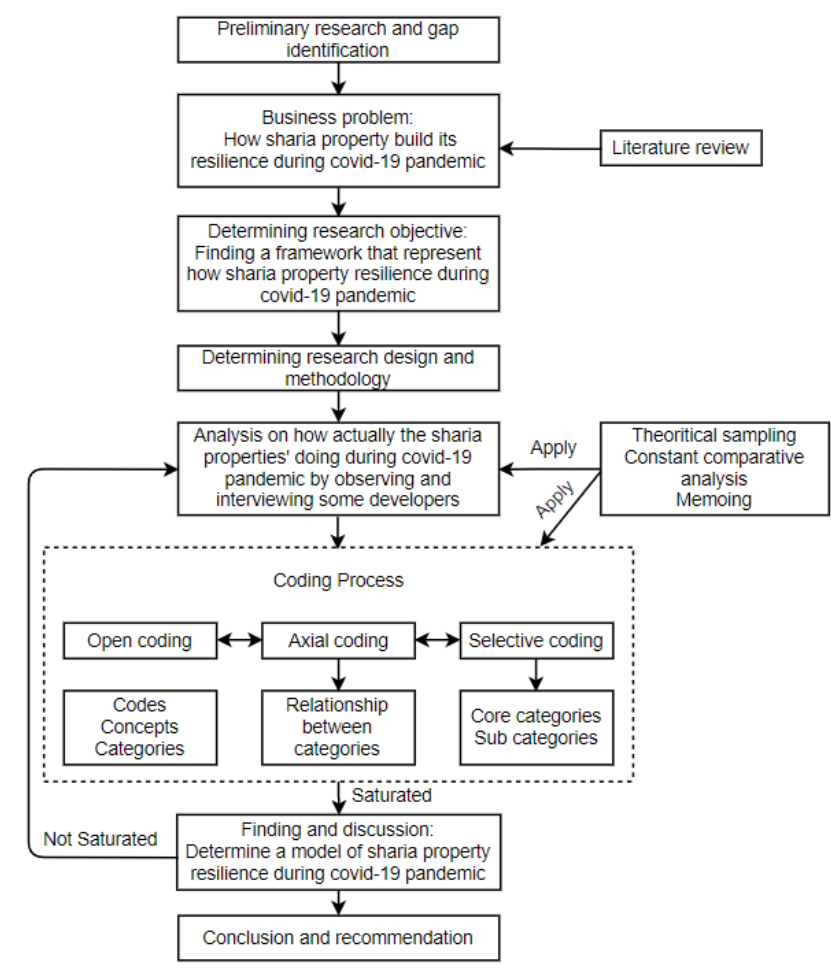

Fig. 6. Research Design.

To analyse the finding, the data in this research is analysed by using grounded theory. Grounded theory uses a series of cumulative coding cycles and reflective analytic memoing to develop major categories for theory generation [21]. Grounded theory is also used to describe a method used to analyze data, the true key goal of GT is to generate a theory grounded in the data [22]. Therefore, based on its purpose, grounded theory is primarily a research design, as well as a method of data analysis.

During the interview, author recorded and transcribed expost interviews to capture every bit of information [23] and obtained approximately 39 transcript pages. To enhance the understanding of the cases and triangulate data from interviews, author relied on secondary data. To emphasize the grounded theory, author did some coding steps to synthesize the interview results. Coding is also a heuristic - a method of discovery. Determining the code for a chunk of data by careful reading and reflection on its core content or meaning [21]. There are three elemental methods that serve as foundation approaches to coding [21]: (1) Descriptive, (2) In Vivo, and (3) Process coding. Particularly in this research, author is combined both in vivo and process coding while translate interview transcripts into codes, because sometimes interviewee use their own language/ terms which are related to the business.

\section{FINDINGS AND RESULTS}

\section{A. Analysis of Business Situation: Sharia Property Readiness during COVID-19 Pandemic Shock}

Based on the field observation and interview, there are several problems occurred during the COVID-19 pandemic, especially during lockdown around March-May 2020, most of the project experience declines in sales because at that time, there are restrictions to move freely, and property required physically meeting to check location and other things. Besides that, some installments are not fully paid due to restrictions that affected users' income. Moreover, most of users are coming from informal sectors, whom very affected because of this policy. Although, the developer already allocates their cashflow well to anticipate this kind of condition. Developer is already prepared the worst scenario to be its contingency plan

Based on the interview, author found that sharia property was able to apply its capability to adopt the business to the situation by holding the sharia principle and values, updating, and ensuring its knowledge to let the business run although the condition is unfavorable. This kind of knowledge sharpen over time and experience. These factors that drives the capabilities of sharia property to grow in building its resilience. According to the respondent, before COVID-19 pandemic, sharia property has experienced shocks, one of the biggest is in 2019 which sales is quite low, in addition, there are bad rumours about sharia property. Some said that sharia property is full of fraud, but, in fact, the condition is not as people's thought. According to the respondent, honestly, those developers (which did fraud) do not have basic knowledge about cashflow management, in addition, they might not have a value and principle about sharia itself. They just see it is as business, meanwhile, sharia property might see this business as a da'wah too. Because it is different with other business that is strict with "strict rules", but, in this business, all the rules are negotiable to comfort the users. The basis of this business is a trust and communication.

\section{B. Conclusion of Business Situation}

Based on observation and interview analysis, it can be concluded that sharia property has several themes or concepts to be resilient through crisis, especially during COVID-19 pandemic. As Fig. 7 explanation, it shows that the resilience of sharia property is related to 12 concepts and 4 aggregate dimensions. These concepts represent dynamic capability of sharia property developer through its knowledge that drives it to be resilient. The knowledge is about their understanding about sharia itself, sharia transaction, and how sharia property began to establish back then in 2014. The knowledge always grows year by year and they already faced similar situation that can be defined as a shock. Knowledge about maintaining good relationship and communication, also managing cashflow management are always updated. So, in this kind of situation, the business can run as usual meanwhile, there is 
also a different situation and result with common situation if COVID-19 pandemic did not happen.

\section{Strengthening Commitment}

\section{Doing business as a part of da'wah}

Author's analysis indicates that every key resource has the same value that they hold. So, even though, how hard the problem that they face, they always remember their value to run this business.

Even though there are ups and downs in starting this business, however, always strive to always be closer to Allah SWT. We have the belief that when defending Allah's religion, there must be help from Him (General manager, Gresik)

If I was asked to tell you how we survived in 2020, we couldn't tell. Why? Because it's more about a miracle than just a business process and because we do business "with Allah", we often feel Allah's help. And it cannot be felt by people who are not in a part of da'wah. In 2020 there is a lot of Allah's help. Stories like this, if people don't understand da'wah, it's like a miracle. We believe, if people are obedient to Allah, Allah will surely help (Head of marketing, Surabaya).

So, based on this quotation, it shows that the key resources have point of views to always hold their value even though the situation is unfavorable to run business. Most of the employee are fear and overwhelmed in this situation, because they might face a risk of losing their job, moreover during the lockdown where there are no sales in that time. In addition, there are several users who delayed their payment or paid only half of their installments. But, as a leader, the general manager and head of marketing are always focused on sales and calming these worries by giving reminder to their team that this business is a part of da'wah, if they do it sincerely, Allah will guide them to His help. In this kind of situation, leader plays a main role to drive the organization to be confident as their commitment to run this business in the name of Allah.

First order concepts

Second order concepts

Aggregate dimensions

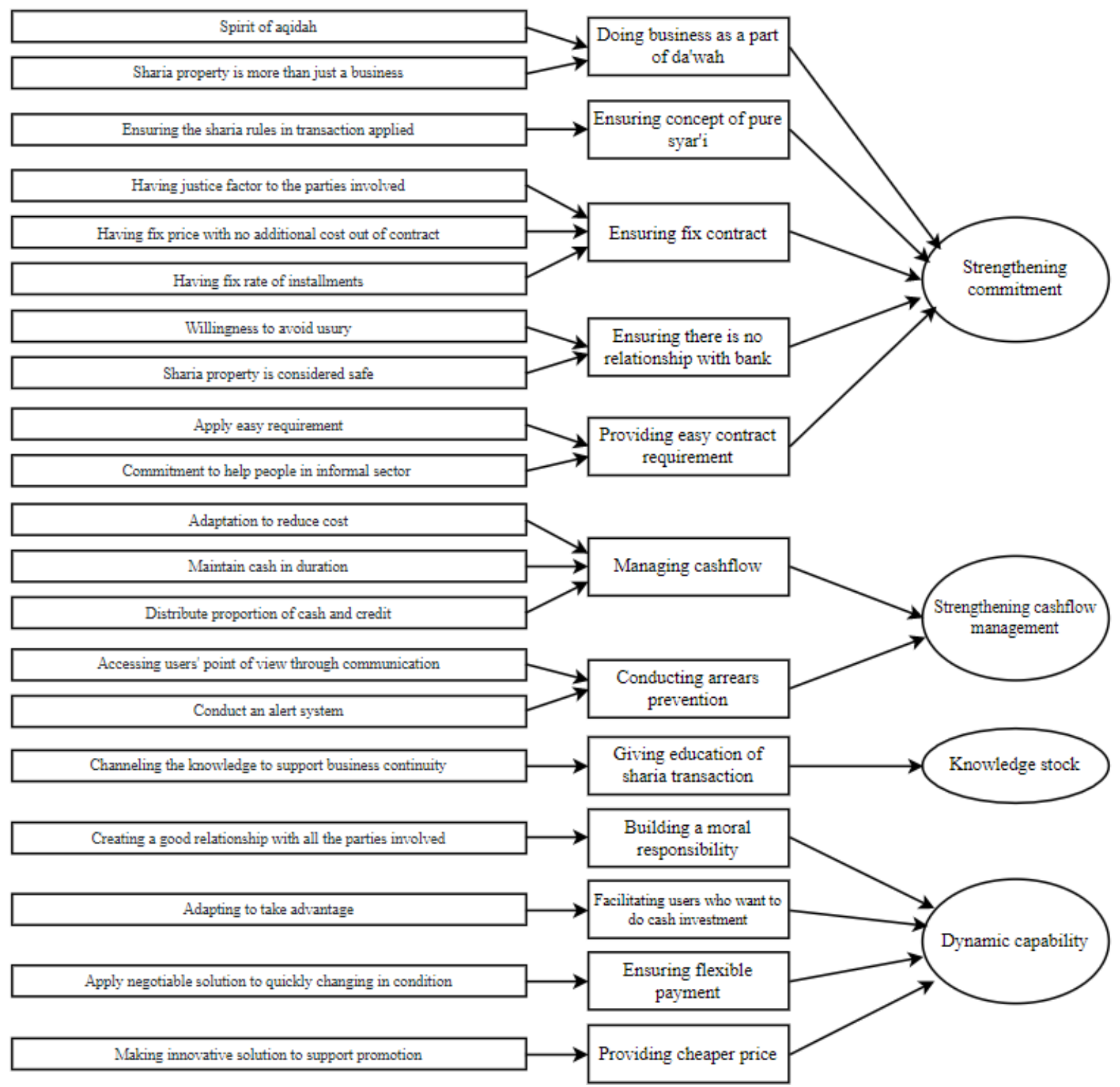

Fig. 7. Final Data Structure. 
In spite of the negative impact of the COVID-19 pandemic, all of the employee was able to manage the situation effectively. The activity was running as usual, the marketing process and other things were running as usual. Even though, the sales were decreasing, they were still working and even harder. Why is it harder? Because it does not talk about the business as usual, but it is a commitment to spread the knowledge through da'wah. Employee was not stop working even though some might be not working at an office as usual, but they were mobile. Their commitment to involve in da'wah to spread a good value, never going to be stopped by any condition. Their belief that Allah will guide them to His help is always be held by anyone in this business. If they do not keep this in their mind, maybe the business is not going to be resilient until now. If people just see this is only a business, maybe when it is shaken by crisis, they might be giving up of the situation. Contrary, they do all their work sincerely and always pray to hope some help from their creature. They have belief that if they keep the da'wah, Allah will help no matter what, even though it seems to be impossible. Firms are likely to strengthen their commitment, since they consider "that an ongoing relationship with another is so important to warrant maximum efforts at maintaining it...to ensure that it endures indefinitely" [24]. Organization should perform sense making processes to restore members' social identification that is key to their commitment and performance [25].

\section{Ensuring concept of pure syar' $i$}

It is a commitment from them to keep away something usury because they want their home to be blessed by Allah. In addition, they have a point of view that home is something that related to our life where it become an environment to our child and family and a place to learn, people must consider and know the essential of buying a syar'i.

This sharia property has a mission to educate people so that people can avoid the sin of usury. We are taught to study fiqh muamalah (fiqh to explain buying and selling transaction contracts) and ensure that there is no usury, gharar, and dzolim.... (General manager, Gresik)

Islam requires every Muslim to fulfill his obligations while trying his best to stay away from His prohibitions solely in the context of obedience to Him, in this context is to stay away from usury. A Muslim must be aware of the prohibition of usury by not taking conventional banks to meet their home financing needs [26].

\section{Ensuring fix contract}

Ensuring contract is a part of commitment that developer offered to their customer. In this situation, people tend to avoid uncertainty. In the other side, company (in this term is developer), is going to secure its business by keeping the commitment as they used to be. It is also a part of their capability to be more developed in order to meet the needs. Based on the interview, people tend to be interested in sharia property because of this justice factor, which means that every party involved in this business is get advantage. The additional costs like notary fees, tax fees should include in the price that is offered to customer. In addition, the commitment of offering flat pricing in the monthly installment payment system affects someone to buy sharia property [27].

\begin{abstract}
Many people are interested in sharia property because of the justice factor... (General manager, Mojokerto)

Sharia property has a fixed down payment, there are no additional costs. Meanwhile, most conventional developers exclude tax fees, notary fees, etc., so that they seem cheaper, even though there are some additional costs when the contract has taken place... (Marketing, Mojokerto)
\end{abstract}

\section{Ensuring no relationship with bank}

Based on the interview, during the lockdown, many people took and save their cash from bank, just in case something urgent happened. In addition, some information and news regarding banking in recent months seem to have become a fluctuation in banking [28]. News of the troubled seven banks and the potential for non-performing loans to increase during the COVID-19 pandemic are negative issues that will reduce public trust and confidence in the banking industry.

It causes people who have cash a decrease in trust to save their money in the bank and try to invest in real sector, such as property. Some of the customer choose to invest in sharia because they avoid associating with bank. Developer tends to maintain its commitment to avoid a relationship with bank, because there are people who have a point of view to avoid bank in making transactions. And lately in the beginning of pandemic COVID-19, some banks experienced nonperformance loan that implies to the problem of their liquidity. Bank became very strict to give a credit for people, and some people considered to find the other way. Some of people who considered to open business in the year of COVID-19 pandemic, started to think that the business might not run well because the growth of economic is slow. So, people considered that it is safer to invest in sharia property.

From the developer point of view, it is more than just a commitment, but it is also a mandate for them to always run the business, even though the condition is hard. People already valued that sharia property to be a large "brand" to be compared with the conventional one. It is a part of principle which always be held tightly although in the middle of crisis like pandemic COVID-19.

During the lockdown, the conditions were that these people really kept their cash and in banking there was also a money rush, many customers took cash. His (refers to God) help is directed at people who save cash which they then turn to property. They don't want conventional property, they want sharia, why? Because it is not connected to banking (Head of marketing, Surabaya)

Sharia property is not dependent on banks, so if a crisis occurs which then hits the banking sector, sharia properties can survive and resilient (Marketing, Mojokerto)

\section{Providing easy contract requirement}

Based on the interview, providing easy contract requirement is a part of sharia developer's commitment to maintain its business run well. In this condition, some people are affected by COVID-19 pandemic, some might get decrease in income/ salary or get a decrease in sales, for 
someone who run a business. When it comes to the condition to apply credit in bank, some of them might be rejected because of their capability to pay is low, in banks' point of view. Sharia developer has a commitment to apply easy requirement, so that many people can buy house and avoid the sin of usury.

The business resilience of sharia property is achieved through the commitments they held for years. A basis of trust and commitment become a good combination to be able to face this condition. In the beginning of the establishment, sharia property is opened for people from the informal sector who does not have a salary slip, but the developer still considered their trust and commitment to give their best in giving service. In years, people who is helped by the existence of sharia property, feel satisfied with this commitment. It will increase their public trust, moreover in this "hard" condition.

In fact, many users have finally decided to buy a house at a sharia developer because the conditions are easy and simple, only with an ID card, family card, and down payment (General manager, Tuban)

People who like long loans in conventional properties, but are not qualified by BI checking requirements, they are from the informal sector who do not have salary slips. Most of our users are not employees, mostly entrepreneurs and traders or even freelancers who don't have a salary slip. They are people who are helped by the existence of sharia property (Marketing, Mojokerto)

\section{Strengthening Cash Flow Management}

\section{Managing cash flow}

A resilient business is one with sufficient funds for operations and growth, now and in the future. Managing cash flow is crucial, especially in a tough business environment [29]. In uncertain times, cash remain the only oxygen businesses required to survive, hence there is the need to keep operations going to ensure financial stability [30]. In times of uncertainty, cash is king [17], so, when the big cash came in, developer is happy. It means, they be able to survive in managing their costs as well as their income. In d'Ahsana and maxipro's project, both want to build their effective cash management. Effective cash management includes creating timely cash flow projections while looking for ways to reduce variable costs, considering alternative or non-traditional revenue streams and getting clarity on available credit facilities [31]. Sharia property lies in time so the financing can be arranged more flexible, but in this time of crisis, if the cash inflow is reduced, it means that other costs also should be managed. During the pandemic, the activity of some employee was done outside the office, the head office is temporary closed due to "work from home" system to reduce the cost.

During this pandemic, that makes it doesn't collapse is when big cash comes in. Well, property developer that is able to survive is the developer who plays in this middle class. For example, in Ahsana Mojokerto itself, there is no need billion rupiah to run a business, but with only hundreds of million rupiah, the project can already run. we do not build projects all at once, but gradually, because we pay attention to cashflow management aspects so that projects can run well (Marketing, Mojokerto)

During this COVID-19 pandemic, many people have cash, but not big, between 100-200 million. Initially for business, but in conditions of the COVID-19 pandemic like this, it is not necessarily profitable, in fact there is a high possibility of loss. Therefore, many people invest their money in property with discounted schemes, with the consequence of a longer period of pre order. Actually, with the price of 195 million, the user has profited because the market price of housing around here has reached 400 million (CEO, Sidoarjo)

\section{Conducting arrears prevention}

Companies affected by the COVID-19 outbreak may experience cash flow challenges as a result of disrupted operations, higher operating costs or lost revenues. They may need to obtain additional financing, obtain waivers if they no longer satisfy debt covenants [30]. Based on the interview, many people (users) have experienced a decrease in their income, and some of them applied for postponing their installments. Developer and user were conducting two-ways communication to get a win-win solution to address this problem.

When there is a COVID-19 pandemic like this, when payments from users are postponed, the team also helps to explain that this also has an impact on the setback of the project timeline, thus creating a two-way communication that is mutually understanding between both parties (CEO, Sidoarjo)

The maximum installment is 10 years, usually we also create an "alert system" to minimize people who are in arrears. For example, the person's installments are 3 million, meaning, in a year, at least 36 million must be collected (Head of marketing, Surabaya)

Then, in the era of new normal, developers were adapted and prepared with this kind of condition that required to creat an alert system to minimize people who are in arrears. It is a preventive action to avoid the problem in managing cashflow, because cash is needed to run and maintain the business and conduct the business continuity to grow and profitable. The alert system is used to mapping the credit/ installment on track, if in certain times, the user cannot fulfil the payment, they should conduct a meeting to discuss about this, whether it is needed to be restructured or something.

\section{E. Knowledge Stock}

\section{Giving education of sharia transaction}

This concept is related to the dynamic capability, where a leader can improve their capability to share their knowledge and at the same time, they have to utilize it both educate about sharia transaction whether is halal and haram and to promote their products. So, it is not only about business, but it is a part of da'wah and education to avoid usury and other haram things. Most of the practitioners in this business have an adequate educational background in sharia, so they use it to 
resilience their business, it is accordance with a quotation by head of marketing in Surabaya.

However, once again, this is a part of an effort to educate people and da'wah to avoid the sin of usury. We here must be filled with people who are sincere in running a business and da'wah at the same time (Head of marketing, Surabaya)

It is important to educate potential users about sharia properties, how to pay them, why it needs a big amount of down payment, then an easy comparison of sharia and conventional properties is given. If potential users understand this, they will feel safe in transactions because trust has arisen (Marketing, Mojokerto)

Based on the quotation above, knowledge stock is important owned by the employee, moreover the employee who are related with end-user, because the basis of this business is about trust and communication. During COVID19 pandemic, sharia property experienced decrease numbers in sales, but it requires a creativity for people in marketing to attract potential users in order to build a business resilience. Based on the interview, marketing manager said that knowledge stock is important to be owned by marketing, as simple as making comparation between sharia and conventional property, then making a brief explanation with a simple illustration to give understanding about what sharia transaction is and what sharia property is.

The more education that people get, the more understanding that they will be obtained. In general, religiosity related to conditions (religious knowledge, religious beliefs) that can influence what is done with emotional attachment too emotional feelings about religion and behavior. So Muslim consumers must be selective in choosing a product. The more information obtained, the consumer's knowledge about the brand is increasing [27].

\section{F. Dynamic Capability}

\section{Building a moral responsibility}

This is a type of dynamic capability, where there is a good relationship among stakeholders. Each stakeholder is responsible their stake. Dynamic capabilities, understood as reconfiguring a company's resource base in order to better sense and seize opportunities, are seen as one of the key drivers of a firm's performance in changing environments [32]. Building a moral responsibility has a relationship with obtaining methods of financing, because developer needs to build a responsibility of their users to morally pay the installment. The ability to obtain this, is captured from how the developer direct their user to be obey. They conduct a good communication, maximize their capability to listening to their user, observing the problem (if any), and finding solution over a problem (if any).

Our strategy is just a reminder and if they still don't pay, we pray for them. We do not scold the user, instead we pray that they will be given rizqi (General manager, Mojokerto)
In 2020, what will our billing look like? We experienced late billing and we receive installment that amount less than the installment value that should have been paid, for example the installment value to be paid was 2 million, however, at that time, the customer was only able to pay 1 million, so we still received it, rather than not paying in installments at all (Head of marketing, Surabaya)

At the beginning of the COVID-19 pandemic, many users came to the office to ask for a payment to be postponed. Because the developer understands these conditions, it is also impossible to refuse, finally the decision is accepted. The decision from the developer was warmly welcomed by the users, and in the following months some paid double, some were paid off immediately (CEO, Sidoarjo)

Besides, developer always conduct a good relationship with their user, they always build a good relationship and communication with the other parties like land owner, material shops, and craftsmen. Developer optimistically maximizes their capability in building moral responsibility, in order to maintain their business continuity. Because in the hard time like COVID-19 pandemic, they must manage some problem regarding financing, marketing, and operation as well, so each of this might be maintained well in order to be resilient in this business.

\section{Facilitating users who want to do cash investment}

During COVID-19 pandemic, some people have a cash inhand that originally used for business, but it seems unfavorable to do. Then, some of them became an investor to invest their money in sharia property. If previous years before the pandemic, most of the people bought to occupy it to be occupied by themselves, but now, some people seek this as an opportunity to invest to it. Based on the interview that author conduct, in some projects, one of them is in Sidoarjo, there are a discount if people buy in cash. It is good for both parties, because developer needs cash and people needs to secure their money. This is also a part of innovation by maximizing their capability to conduct an interesting promotion.

During COVID-19 pandemic, people prefer to buy cash because some of the money in the bank, ultimately prefers to invest in property, plus currently property prices are also being "discounted" (General manager, Gresik)

\section{Ensuring flexible payment}

Based on the observation and interview, flexible payment has been a value that sharia property has since its establishment. Another prerequisite of value creation during crises is being able to meet the customer demand for products that offer unique value [32]. The developer can drive this value into their capability to be resilient. Since the beginning, user receive a flexibility of transaction process. As the COVID-19 arisen, the condition might be changed, and it also changed the behavior of the user in paying the installment. But developer enhance their capability to understand what is happened. With a belief that if the situation getting better, the user must fulfil their responsibility. 
At the beginning of the COVID-19 pandemic, many users came to the office to ask for a payment to be postponed. Because the developer understands these conditions, it is also impossible to refuse, finally the decision is accepted. The decision from the developer was warmly welcomed by the users, and in the following months some paid double, some were paid off immediately (CEO, Sidoarjo)

\section{Providing cheaper price}

Cheaper price in this discussion is about innovation through the developer's capability to maintain business resilience. It is along with the capability to manage cashflow, as an explanation before, respondents said that the cash is needed to maintain business, while the investor might receive the house longer than it should, but it is a win-win solution for both of the parties, to be resilient. It also has a relationship with the capability of developer to hold a commitment of applying an easy requirement for people who want to buy house. So, this is the combination of the existing capability with an innovation to be resilient in current condition.

During the COVID-19 pandemic, which transacted with cash discounts, increased dramatically (CEO, Sidoarjo)

During this COVID-19 pandemic, investors see that this is a momentum to buy because the price is cheap and it is believed that in the next few years it will increase (General manager, Tuban)

\section{G. Business Resilience Model}

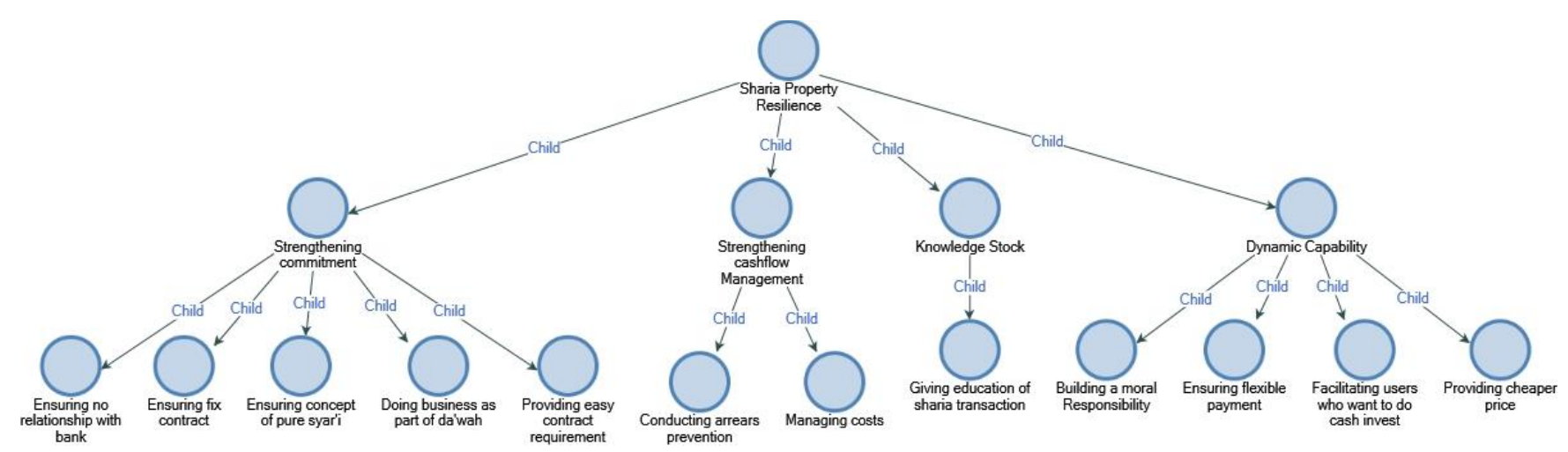

Fig. 8. Business Resilience Model.

\section{CONCLUSIONS}

The model that has been developed in this study, is synthesized though the previous and related literature about resilience. This study responds to the current situation of COVID-19 pandemic, regarding the impact of it specifically to the sharia property sector. This business resilience model for sharia property consists of four dimensions that have been built by the sharia developer to be resilience in this COVID19 pandemic shock. The four dimensions are, strengthening commitment, strengthening cashflow management, knowledge stock, and dynamic capability. The long process of processing the raw data of transcription and coding process, hopefully can give impact to the related topics which is rarely discussed.

From this study, the practical implication, this study is focused on sharia property which is getting "huge" shock during this COVID-19 pandemic, especially in the beginning of pandemic. From this study, it can be determined that if this business can build and maintain its resilience, it should pay attention to the four dimensions which are proposed, strengthening commitment, strengthening cashflow management, knowledge stock, and dynamic capability. These dimensions are critical to maintain the sharia property business. This model can be used for other companies in the same field to apply through a huge shock as COVID-19 pandemic crisis.

\section{REFERENCES}

[1] C. Sohrabi et al., "World Health Organization declares global emergency: A review of the 2019 novel coronavirus (COVID-19)," Int. J. Surg., vol. 76, no. February, pp. 71-76, 2020, doi: 10.1016/j.ijsu.2020.02.034.

[2] Worldmeter, "Coronavirus Cases - Worldometer," https://www.worldometers.info/coronavirus/, 2021. .

[3] B. Nugraha, L. K. Wahyuni, H. Laswati, P. Kusumastuti, A. B. Tulaar, and C. Gutenbrunner, "COVID-19 pandemic in Indonesia: Situation and challenges of rehabilitation medicine in Indonesia," Acta Med. Indones., vol. 52, no. 3, pp. 299-305, 2020.

[4] S. T. Ponis and A. Ntalla, "Crisis Management Practices and Approaches: Insights from Major Supply Chain Crises," Procedia Econ. Financ., vol. 39, no. November 2015, pp. 668-673, 2016, doi: 10.1016/s2212-5671(16)30287-8.

[5] M. Nicola et al., "The socio-economic implications of the coronavirus pandemic (COVID-19): A review," Int. J. Surg., vol. 78, no. March, pp. 185-193, 2020, doi: 10.1016/j.ijsu.2020.04.018.

[6] M. Sohlberg, "Indonesia Property Market Outlook 2020: A Complete Overview," https://www.asiapropertyhq.com/indonesia-propertymarket/, 2021. .

[7] C. Ferlito, "Kondisi Ekonomi dan Pasar Properti Indonesia Setelah," no. June, 2020, doi: 10.13140/RG.2.2.34691.53285.

[8] Bank Indonesia, "Residential Property Survey," 2021. [Online]. Available: https://www.bi.go.id/en/publikasi/survei/harga-propertiprimer/Default.aspx.

[9] Otoritas Jasa Keuangan, "Statistik Perbankan Indonesia," Indones. Bank. Stat., vol. 18, no. 12, 2020, [Online]. Available: http://www.elsevier.com/locate/scp.

[10] Real Estate Indonesia, "Bisnis Properti Syariah Bakal Tumbuh di Atas 10 Persen," https://www.rei.or.id/newrei/berita-bisnis-propertisyariah-bakal-tumbuh-di-atas-10-persen.html, 2021. http://rei.or.id/newrei/berita-bisnis-properti-syariah-bakal-tumbuh-diatas-10-persen.html.

[11] I. Budhiman, "Bagaimana Nasib Bisnis Properti Syariah di Tengah Pandemi Corona," https://ekonomi.bisnis.com/read/20200511/47/1239184/bagaimananasib-bisnis-properti-syariah-di-tengah-pandemi-corona, 2021.

[12] Dirwan, "Pengaruh Tingkat Religisitas pada Keputusan Buying 
Properti Syariah Non Bank (Studi Kasus pada Buyer Griya Baiti Jannati Residence)," vol. 2, pp. 53-75, 2019, doi: 10.5281/zenodo. 2649815 .

[13] K. Ratnasari, "Mengenal Seluk Beluk Properti Syariah: Ciri Khas, Sistem KPR, Hingga Developer Syariah,' https://artikel.rumah123.com/mengenal-seluk-beluk-properti-syariahciri-khas-sistem-kpr-hingga-developer-syariah50353\#DFyAMetC6FEwdUz7.99, 2021.

[14] B. Zohuri and M. Moghaddam, "A General Approach to Business Resilience System (BRS)," Scifed J. Artif. Intell., vol. 1:3, no. September, 2018

[15] J. Fiksel, "Designing Resilient, Sustainable Systems," Environ. Sci. Technol., vol. 37, no. 23, pp. 5330-5339, 2003, doi: 10.1021/es0344819.

[16] B. Walker et al., "Resilience Management in Social-ecological Systems : a Working Hypothesis for a Participatory Approach," vol. 6, no. $1,2002$.

[17] Coupa, "Building Resilience in Times of Business Uncertainty," 2020.

[18] C. Palmer and A. Bolderston, "A Brief Introduction to Qualitative Research," vol. 5930, no. March 2006, 2018, doi: 10.1016/S08205930(09)60112-2.

[19] A. Cropley, "Introduction to Qualitative Research Methods," pp. 0188, 2019, doi: 10.13140/RG.2.1.3095.6888.

[20] N. Mack, C. Woodsong, K. M. MacQueen, G. Guest, and E. Namey, Qualitative Research Methods: A Data Collector's Field Guide. 2005.

[21] M. B. Miles, M. Huberman, and J. Saldana, Qualitative Data Analysis: A Methods Sourcebook, 3rd ed. California: SAGE Publishing, 2014.

[22] C. Biaggi and S. Wa-mbaleka, "Grounded Theory: A Practical Overview of the Glaserian School," no. July, 2018, doi: 10.7719/jpair.v32i1.573.

[23] M. Bergami, M. Corsino, A. Daood, and P. Giuri, "Being resilient for society: evidence from companies that leveraged their resources and capabilities to fight the COVID- - 19 crisis," pp. 1-20, 2021, doi: 10.1111/radm.12480.

[24] R. M. Morgan and S. Hunt, "The Commitment-Trust Theory of Relationship Marketing," J. Mark., vol. 58, no. December, 1994, doi: 10.2307/1252308.

[25] F. Bahri Korbi, K. Ben-Slimane, and D. Triki, "How do international joint ventures build resilience to navigate institutional crisis? The case of a Tunisian-French IJV during the Arab-Spring," J. Bus. Res., vol. 129, no. February, pp. 157-168, 2021, doi: 10.1016/j.jbusres.2021.02.059.

[26] M. R. Hidayah, K. Nawawi, and S. Arif, "Analisis Implementasi Akad Istishna Pembiayaan Rumah (Studi Kasus Developer Property Syariah Bogor)," Ekon. Islam, vol. 9, pp. 1-12, 2018.

[27] G. F. W. Al Qorni, "Keputusan Pembelian Properti Syariah Tanpa Bank: Analisis Pengaruh Faktor Harga, Lingkungan Perumahan dan Religiositas," 2020.

[28] Y. B. Suhartoko, "Bagaimana pandemi COVID-19 bisa memicu krisis perbankan di Indonesia," https://theconversation.com/bagaimanapandemi-covid-19-bisa-memicu-krisis-perbankan-di-indonesia142559, 2021. https://theconversation.com/bagaimana-pandemicovid-19-bisa-memicu-krisis-perbankan-di-indonesia-142559.

[29] Salisbury, "Business Resilience: Through Precise Cash Flow Management," https://www.salisburys.net.au/business-resiliencethrough-precise-cash-flow-management/, 2021. .

[30] B. Alao and L. Oladejo, "Coronavirus Pandemic and Business Disruption : The Consideration of Coronavirus Pandemic and Business Disruption: The Consideration of Accounting Roles in Business Revival," no. May, 2020

[31] CPA Ontario, "Business Continuity with Effective Cash Flow Management | CPA Ontario," https://www.cpaontario.ca/covid-19. resources/business-continuity-with-effective-cash-flow-management, 2021. https://www.cpaontario.ca/covid-19-resources/businesscontinuity-with-effective-cash-flow-management.

[32] W. Dyduch, P. Chudzi, S. C. Id, and M. Z. Id, "Dynamic capabilities , value creation and value capture : Evidence from SMEs under Covid19 lockdown in Poland," PLoS One, vol. 16, pp. 1-28, 2021, doi: 10.1371/journal.pone.0252423.

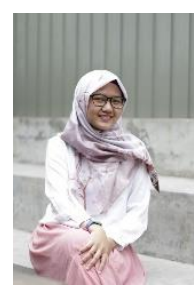

A. A. Fauzi is a student in Master of Business Administration, Institut Teknologi Bandung. She completed bachelor degree in Faculty of Agro-industry Technology, Universitas Gadjah Mada. She has published a proceeding about business strategy. She is interested in research area that related to business strategy, business continuity, and property.

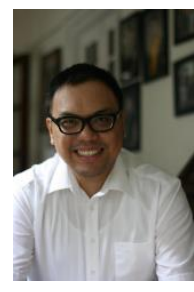

R. A. Rahadi has direct experience working for 18 (eighteen) years in real estate, property, architecture, design, investment management, financial consulting, and research. Holds a bachelor degree in Architecture Engineering from Bandung Institute of Technology, hold two master degrees in Management from Swiss German University, Indonesia and in Business Administration from Fachhochschule Konstanz-Hochschule für Technik Wirtschaft und Gestaltung, Germany, holds a Doctorate degree in Management Science from School of Business and Management, Bandung Institute of Technology. Holds Qualified Wealth Planner (QWP $\left.{ }^{\circledR}\right)$ certification from IAFP Global, International NLP Basic Practitioner Certificate from National Federation of Neuro-Linguistic Programming (NFNLP), and Registered Financial Associate (RFA $\left.{ }^{\circledR}\right)$ Certificate from International Association of Registered Financial Consultants. 